\title{
STUDY EMPIRIS PENILAIAN LAPORAN KEUANGAN BANK SYARIAH DI INDONESIA BERDASARKAN STANDAR IFRS DAN AAOIFI
}

\author{
Nur Afifah Kumalasari Mulyadi \\ Jurusan Akuntansi, Universitas Muhammadiyah Palopo \\ nurafifahkumalasarimulyadi23@gmail.com
}

\begin{abstract}
ABSTRAK
Penelitian ini bertujuan untuk mengukur seberapa jauh perbankan syariah Indonesia mengadopsi standar AAOIFI dan IFRS dalam pelaporan keuangannya. Penelitian ini menggunakan laporan tahunan bank syariah Indonesia dengan periode tahun 2014- 2018 yang diperoleh dari 11 bank syariah di Indonesia yang dikumpulkan dari web resmi kesebelas bank yang dijadikan sampel. Penelitian ini menggunakan pendekatan kuantitatif dengan menggunakan metode analisis isi (Content Analysis). Hasil penelitian ini menunjukkan bahwa perbankan syariah Indonesia lebih condong mengadopsi standar IFRS dalam laporan keuangan tahunannya (annual report), hal ini dapat dibuktikan dengan besarnya jumlah persentase perbankan syariah yang dominan memenuhi total item yang dipilih sebagai standar IFRS dalam laporan keuangannya, dibandingkan dengan jumlah persentase perbankan syariah yang memenuhi total item yang dipilih sebagai standar AAOIFI.
\end{abstract}

Kata Kunci : Bank Syariah, IFRS, AAOIFI

\begin{abstract}
This study aims to measure how far Indonesian Islamic banking adopts AAOIFI and IFRS standards in its financial reporting. This study uses the annual report of Indonesian Islamic banks in the period 2014-2018 obtained from 11 Islamic banks in Indonesia compiled from the official website of the eleven banks that were sampled. This research uses a quantitative approach by using a Content Analysis method. This study's results indicate that Indonesian Islamic banking is more inclined to adopt IFRS standards in its annual financial reports (annual report). It can be proven by the large number of percentages of Islamic banking that predominantly meet the total items selected as IFRS standards in its financial statements, compared to the percentage Islamic banking that matches the total items selected as AAOIFI standards.
\end{abstract}

Keywords: Islamic Banks, IFRS, AAOIFI

\section{PENDAHULUAN}

Akuntansi merupakan bahasa bisnis utama di pasar modal. Semua stakeholder, memerlukan informasi keuangan yang transparan, tepat waktu, efektif dan relevan dari banyak perusahaan yang bisa diperbandingkan. Ini dapat terwujud dengan adanya standar akuntansi. Namun, adanya perbedaan praktek akuntansi yang diakibatkan oleh perbedaan standar akuntansi menyebabkan daya banding tersebut menjadi berkurang bahkan dapat sama sekali hilang. Laporan keuangan perusahaan di suatu negara dengan laba atau kinerja baik, bila disusun dengan standar akuntansi dari negara yang berbeda bisa saja akan menunjukkan perbedaan yang sebaliknya (Azis 2012)

Tentu saja timbul suatu masalah ketika standar akuntansi yang dipakai di negara tersebut berbeda dengan standar akuntansi yang dipakai di negara lain. Keanekaragaman standar yang dipakai menjadi kendala investor dan kreditor serta calon investor dan calon kreditor dalam memahami laporan keuangan yang disajikan. Hal tersebut yang mendorong timbulnya standar akuntansi internasional / International Financial Reporting Standard (IFRS) yang dirumuskan 
oleh IASB (International Accounting Standard Board) (Lestari 2013).

International Financial Reporting Standard (IFRS) merupakan standar pelaporan keuangan yang dapat diterima secara internasional atau global. Standar akuntansi Internasional yang diterbitkan oleh International Accounting Standard Board (IASB), merupakan lembaga independen untuk menyusun standar akuntansi yang berlokasi di London, Inggris.Organisasi ini memiliki tujuan mengembangkan dan mendorong penggunaan standar akuntansi global yang berkualitas tinggi, dapat dipahami dan dapat dibandingkan (Hermawan and Zunaida 2013).

Meskipun standar IFRS telah diperkenalkan untuk pelaporan umum yang serupa di seluruh dunia, perkembangan lembaga keuangan Islam dan keyakinan yang berkembang memberikan sebuah asumsi yang mendasari bahwa sistem akuntansi keuangan barat tidak kompatibel dengan keyakinan dan nilai-nilai Islam yang telah berkontribusi pada pengembangan penelitian akuntansi Islam dan laporan perusahaan Islam (Haniffa and Hudaib 2007).

Sistem pelaporan keuangan dan prinsip-prinsip akutansi yang berdasarkan prinsip IFRS memiliki sifat yang berbeda dengan lembaga keuangan yang beroperasi berdasarkan prinsip-prinsip syariah International Financial Institution (IFI) sehingga IFI tidak dapat sepenuhnya mengikuti standar- standar IFRS, hal ini dikarenakan IFI memiliki beberapa persyaratan unik, sehingga mereka tidak dapat sepenuhnya mematuhi IFRS dalam pelaporan keuangan mereka, dan dalam banyak kasus, mereka memiliki beberapa aturan yang bertabrakan dengan standar IFRS (Ibrahim 2009)

(Ilahiyah and MAR'A 2012) Mengungkapkan bahwa "IFRS diterima secara luas di seluruh dunia karena lebih dari 115 negara mengadopsi IFRS pada tahun 2008”. Dimana ada beberapa negara juga yang siap untuk konvergensi ke IFRS, termasuk Indonesia, Malaysia dan Pakistan, dimana negara tersebut juga telah mulai mengadopsi standar akuntansi yang berdasarkan standar syariah yaitu Accounting andAuditing Organization for Islamic Financial Institutions (AAOIFI) (Latifah, Asfadillah, and Sukmana 2012). AAOIFI dikenal sebagai organisasi akuntansi keuangan untuk bank syariah dan lembaga keuangan, didirikan sesuai dengan perjanjian asosiasi yang ditandatangani oleh lembaga keuangan syariah pada 1 safar, $1410 \mathrm{H}$ atau bertepatan dengan 26 Februari 1990 di Aljazair. AAOIFI didaftarkan pada 11 ramadhan $1411 \mathrm{H}$ atau bertepatan dengan 27 maret 1991 dan berdomisili di negara bahrain, dan menjadi sebuah lembaga non-profit internasional (AAOIFI 2002)

(S. W. Nurhayati 2009) Mendefenisikan akuntansi syariah sebagai Muhasabah (akuntansi 
syariah), yaitu suatu aktivitas yang teratur berkaitan dengan pencatatan transaksi-transaksi, tindakan - tindakan, keputusan-keputusan yag sesuai dengan syariat, dan jumlah- jumlahnya, didalam catatan-catatan refresentatif, serta berkaitan dengan pengukuran hasil-hasil keuangan berimplikasi pada transaksi-transaksi, tindakan-tindakan, dan keputusan- keputusan tersebut untuk membantu pengambilan keputusan yang tepat.

Perkembangan akuntansi syariah belakangan ini semakin meluas tidak hanya di Indonesia melainkan di seluruh dunia juga mengalami hal yang sama. Hal ini disebabkan adanya perkembangan dari sistem keuangan islam yang sangat pesat. Peraturan syariah pun mulai disusun untuk menunjang perkembangan akuntansi agar memiliki kedudukan yang jelas dalam suatu negara, di Indonesia sudah beberapa kali mengadakan perubahan terhadap peraturan akuntansi syariah sehingga ada sedikit penyesuaian yang dilakukan pada penerapan akuntansi syariah yang ada di Indonesia (Widiana 2017). Dilihat dari beberapa hal, bank konvensional maupun bank syraiah memiliki persamaan yaitu dari syarat-syarat umum memperoleh pembiayaan, teknis penerimaan uang, mekanisme transfer dan yang lainnya. Tetapi antara keduanya juga memiliki perbedaan yang mendasar yaitu akad yang dilakukan bank syariah mempunyai konsekuensi duniawi dan ukhrawi sesuai dengan hukum Islam sedangkan bank konvensional hanya mempunyai konsekuensi duniawi saja dan bank syariah menggunakan prinsip bagi hasil sedangkan bank konvensional menggunakan tingkat suku bunga dalam penyaluran dananya.(Purnamasari 2016).

(Ilahiyah and MAR'A 2012) Menyatakan diterapkannya akuntansi syariah adalah untuk mencapai keadilan sosial-ekonomi, dan sebagai bentuk menjalankan ibadah kita dalam memenuhi kewajiban kepada Allah SWT, sebagaibentuk pertanggungjawaban kita terhadap tugas individu dalam melaporkan segala hal yang berkaitan dengan laporan keuangan. Hasil akhir teknik akuntansi syariah berupa informasi akuntansi yang akurat untuk menghitung zakat dan pertanggungjawaban secara horizontal kepada Allah SWT dengan berlandaskan moral, iman, taqwa serta vertikal kepada para pemegang saham (Stakeholder).

Berdasarkan penelitian yang dilakukan (Ullah and Tasnim 2017) Bangladesh telah menetapkan IFRS sebagai standar pelaporan keuangan, namun khusus bank syariah, khusunya Islamic Bank Bangladesh Limited (IBBL) mengadopsi standar IFRS dan AAOIFI dalam pembuatan laporan keuangannya, maka dari itu peneliti tertarik untuk menguji standar yang digunakan perbankan di Indonesia yang telah menetapkan IFRS sebagai standar pelaporan keuangannya, dalam hal ini peneliti akan mengukur seberapa jauh perbankan syariah Indonesia mengadopsi standar AAOIFI dan IFRS dalam pelaporan keuangannya. 
Berdasarkan paparan diatas maka penulis tertarik untuk mengambil judul "Study empiris penilaian laporan keuangan bank Syariah di Indonesia berdasarkan standar IFRS dan AAOIFI"

\section{TINJAUAN PUSTAKA}

\section{Stewardship Theory}

Menurut Danalson dan Davis dalam (Ikhsan and Suprasto 2008), teori Stewardship diperkenalkan sebagai teori yang berdasarkan tingkah laku, perilaku manusia (behavior), pola manusia (model of man), mekanisme psikologis (motivasi, identifikasi dan kekuasaan) dalam sebuah organisasi yang mempraktikkan kepemimpinan sebagai aspek yang memainkan peranan penting bagi sebuah pencapaian tujuan. Teori ini berakar dari ilmu psikologi dan sosiologi yang mengarah pada sikap melayani (Steward)

Stewardship (suatu sikap melayani), merupakan suatu pandangan baru tentang mengelola dan menjalankan organisasi, suatu pergeseran pendekatan pada konsep kepemimpinan dan manajemen yang ada sekarang dari konsep mengendalikan (control) dan mengarahkan, kearah konsep pengaturan, kemitraan, dan kepemilikan secara bersama oleh anggota/tim dalam organisasi, yangmerasa organisasi menjadi sesuatu miliknya ataupun satu kesatuan yang tidak dapat dipisahkan dari diri sendiri. (Ikhsan and Suprasto 2008). Teori stewardship didefinisikan sebagai situasi dimana para steward (pengelola) tidak mendahulukan kepentingan pribadi tetapi lebih mementingkan kepentingan principal (pemilik).

Teori stewardship ini mengasumsikan hubungan yang kuat antara kesuksesan organisasi dengan kinerja perusahaan, sehingga fungsi utilitas akan maksimal dan tujuan sesuai dengan harapan pemilik. Karena steward lebih melihat pada usaha untuk mencapai tujuan organisasi dan bukan pada tujuan individu. Stewardship theory adalah sikap melayani, dimana manajemen mempunyai sikap melayani para stakeholder.

\section{Perbankan Syariah}

UU No. 21 Tahun 2008 tentang Perbankan Syariah menyatakan bahwa Perbankan Syariah adalah segala sesuatu yang menyangkut tentang Bank Syariah dan Unit Usaha Syariah, mencakup kelembagaan, kegiatan usaha, serta cara dan proses dalam melakukan kegiatan usahanya. Adapun definisi bank syariah menurut (Yaya, Martawireja, and Abdurahim 2014). Bank syariah adalah bank yang menjalankan usahanya berdasarkan prinsip syariah yang terdiri atas Bank Umum Syariah (BUS) dan Bank Pembiayaan Rakyat Syariah(BPRS)”. 


\section{International Financial Reporting Standards (IFRS)}

International Financial Reporting Standards (IFRS) adalah standar pelaporan keuangan yang dapat diterima secara internasional atau global, diamana IFRS merupakan lembaga independen untuk menyusun standar akuntansi yang berlokasi di London, Inggris. IFRS merupakan standar pelaporan yang diadopsi oleh International Accounting Standards Board (IASB).Pemerintah Indonesia sebagai anggota G20 (The Group of Twenty) telah sepakat untuk melakukan konvergensi IFRS. Oleh karena itu, IAI pada Desember 2008 telah mengumumkan rencana konvergensi standar akuntansi di Indonesia yaitu Pernyataan Standar Akuntansi Keuangan (PSAK) dengan International Financial Reporting Standards (IFRS) yang merupakan produk dari IASB.Rencana tersebut telah terealisasi mulai tahun 2012.Penerapan ini dilakukan agar kualitas informasi yang disajikan dapat meningkat, sehingga mudah dipahami oleh seluruh pengguna laporan keuangan.(Ganesha and Kiswara 2015)

IFRS merupakan standar tunggal pelaporan akuntansi yang memberikan penekanan pada penilaian (revaluation) profesional dengan disclosures yang jelas dan transparan mengenai substansi ekonomis transaksi, penjelasan hingga mencapai kesimpulan tertentu (Nundini and Lastanti 2014).Standar ini muncul akibat tuntutan globalisasi yang mengharuskan para pelaku bisnis disatu negara ikut serta dalam bisnis lintas negara atau perdagangan bebas. Salah satu tujuan diadopsinya IFRS kedalam standar akuntansi domestik atau PSAK adalah untuk menghasilkan laporan keuangan yang memiliki tingkat kreadibilitas yang tinggi (Gamayuni 2009), meningkatkan transparansi perusahaan dan kualitas pelaporan keuangan sehingga menguntungkan investor (Cahyonowati and Ratmono 2013).

Pengadopsian penuh IFRS pada tahun 2012 merevisi PSAK agar secara material sesuai dengan stadar IFRS versi 1 Januari 2009 yang berlaku efektif tahun 2011/2012, konvergensi IFRS di Indonesia dilakukan secara bertahap. PSAK yang direvisi dan ditujukan dalam rangka tujuan konvergensi PSAK terhadap IFRS adalah PSAK 16 (tentang properti investasi), PSAK 16 (tentang aset tetap), PSAK 30 (tentang sewa) PSAK 50 (tentang instrumen keuangan: penyajian dan pengungkapan), dan PSAK 55 (tentang instrumen keuangan: pengakuan dan pengkuran). Adapun manfaat yang diperoleh dari konvergensi IFRS adalah memudahkan pemahaman atas laporan keuangan dengan penggunaan SAK yang dikenal secara internasional, meningkatkan arus investasi global melalui transparansi, dan menciptakan efisiensi penyususnan laporan keuangan.

Mengadopsi IFRS berarti menggunakan bahasa pelaporan keuangan global, yang akan 
membuat laporan keuangan perusahaan bisa dimengerti oleh pasar dunia (global market) (I. Nurhayati and Maryono 2012) .Oleh karena itu, standar akuntansi keuangan berbasis IFRS wajib diterapkan pada perusahaan- perusahaan yang telah go publik, tanpa terkecuali dientitas syariah, salah satunya di perbankan syariah.

\section{Accounting and Auditing Organization for Islamic Financial Institutions (AAOIFI)}

AAOIFI dikenal sebagai organisasi akuntansi keuangan untuk bank syariah dan lembaga keuangan, didirikan sesuai dengan perjanjian asosiasi yang ditandatangani oleh lembaga keuangan syariah pada 1 safar, $1410 \mathrm{H}$ atau bertepatan dengan 26 Februari 1990 di Aljazair. AAOIFI didaftarkan pada 11 ramadhan $1411 \mathrm{H}$ atau bertepatan dengan 27 maret 1991 dan berdomisili di negara bahrain, dan menjadi sebuah lembaga non-profit internasional (AAOIFI 2002), AAOIFI telah mengeluarkan dua pernyataan standar akuntansi keuangan yang berkaitan dengan tujuan-tujuan dan konsep-konsep akuntansi keuangan bagi lembagalembaga keuangan Syariah, 23 standar akuntasi, 5 standar auditing, 6 standar tata kelola perusahaan, dan 2 kode etik bagi akuntan dan auditor lembagalembaga keuangan Syariah. Sebagai lembaga internasional yang independen, AAOIFI didukung oleh anggota-anggota dari institusi keuangan (saat ini tercatat 155 anggota dari 40 negara) meliputi bank-bank sentral, lembaga-lembaga keuangan Syariah, dan anggota lain dari perbankan dan industri keuangan syariah internasional di seluruh dunia. (Karim 1999) menjelaskan bahwa AAOIFI memiliki mekanisme penyusunan standar-standar akuntansi dan auditing yang cukup memadai. Mekanisme perumusan standar juga melibatkan para pakar Syariah yang tergabung dalam dewan syariah AAOIFI untuk melakukan evaluasi kesesuaian standar-standar dengan prinsip-prinsip syariah. AAOIFI juga menyediakan forum bagi anggota dan pihak-pihak yang berkepentingan dengan standar AAOIFI untuk mengutarakan pendapatnya tentang standar yang diusulkan sebelum akhirnya ditetapkan sebagai standar baku. Proses ini memungkinkan pihak-pihak tersebut untuk mendiskusikan lebih intensif draft awal standar AAOIFI. Hal ini juga merupakan praktik yang lazim dilakukan oleh institusi-institusi perumus standar akuntansi keuangan di berbagai negara termasuk Indonesia (seperti praktik yang dilakukan oleh Dewan Standar Akuntansi - Ikatan Akuntan Indonesia).

Fungsi AAOIFI secara khusus adalah untuk menyediakan standar etika, akuntansi, dan mempertimbangkan semua industri keuangan Islam. AAOIFI juga diharapkan untuk memperkuat efektivitas komite syariah dengan memfasilitasi evaluasi instrumen pendanaan yang sedang berkembang dan dengan membantu dalam penerapan etika Islam (Pomeranz 1997) AAOIFI didirikan untuk memastikan bahwa peserta menyesuaikan diri dengan 
keuangan Islami.

\section{METODE PENELITIAN}

\section{Jenis dan Sumber Data}

Jenis data dalam penelitian ini yaitu data sekunder dimana data sekunder umumnya berupa bukti, catatan, atau laporan historis yang telah tersusun dalam arsip (data dokumenter) yang dipublikasikan dan yang tidak dipublikasikan (Indriantoro and Supomo 2014). Penelitian ini menggunakan data sekunder termasuk laporan tahunan dari 5 (Lima) tahun terkahir yang dikumpulkan dari web resmi kesebelas bank yang dijadikan sampel, literatur yang relevan yang dikumpulkan dari jurnal berbeda dan standar dan informasi lain dari AAOIFI dan IFRS yang dikumpulkan dari masing-masing website.

Sumber data yang digunakan dalam penelitin ini yaitu data dokumen atau dokumenter. Data dokumenter adalah jenis data penelitian yang memuat apa dan kapan suatu kejadian atau transaksi, serta siapa yang terlibat dalam suatu kejadian (Indriantoro and Supomo 2014) yang diperoleh dari laporan tahunan, jurnal, buku, majalah dan artikel publikasi.

\section{Populasi dan Sampel}

Populasi adalah suatu kumpulan menyeluruh dari suatu obyek yang merupakan perhatian peneliti. Populasi dalam penelitian ini adalah seluruh bank syariah di Indonesia yang menyediakan laporan tahunannya serta bisa diakses untuk keperluan penelitian. Sampel adalah bagian dari populasi, dimana sampel dalam penelitian ini adalah laporan keuangan bank syariah Indonesia 5 tahun terakhir, yaitu tahun 2014-2018. Teknik sampling yang digunakan peneliti dalam pemilihan sampel penelitian adalah teknik sampling non probability sampling, dimana pemilihan sampel yang digunakan yaitu purposive sampling, dengan teknik berdasarkan pertimbangan (judgement sampling) yang merupakan tipe pemilihan sampel secara tidak acak yang informasinya diperoleh dengan menggunakan pertimbangan tertentu (umumnya disesuaikan dengan tujuan atau masalah penelitian), (Supomo and Indriantoro 2002) dengan kriteria sebagai berikut :

1. Bank Syariah beroperasi sebelum 2014

2. Menerbitkan laporan tahunan (annual report) periode 2014- 2018, serta bisa di akses

3. Mengungkapkan topik laporan yang sesuai dengan topik penelitian.

\section{Metode Analisis Data}


Untuk menguji kebenaran hipotesis yang dikemukakan sebelumnya, maka metode analisis yang digunakan dalam penelitian ini adalah analisis isi (Content Analysis). Oleh karena itu analisis data yang digunakan dalam penelitian ini bersifat analisis isi kuantitatif, yaitu teknik penelitian ilmiah yang ditujukan untuk mengetahui gambaran karakteristik isi dan menarik inferensi dari isi dengan mengupas suatu teks dengan objektif untuk mendapatkan gambaran dari suatu isi apa adanya, tanpa campur tangan peneliti, dimana hasil analisis isi benar-benar mencerminkan isi dari suatu teks dan bukan akibat subjektifitas peneliti (Eriyanto 2004).

\section{Definisi Operasional}

\section{Standar AAOIFI}

Dalam penelitian ini, peneliti akan menggunakan beberapa item yang diperlukan sebagai standar AAOIFI dan IFRSdiantaranya:

\begin{tabular}{|l|l|}
\hline No & Kategori Item Yang Diperlukan \\
\hline 1. & Ketentuan Umum laporan keuangan \\
\hline 2. & Pengungkapan Umum Dalam Laporan Keuangan \\
\hline 3. & Laporan Posisi Keuangan (Neraca) \\
\hline 4. & Laporan Laba Rugi \\
\hline 5. & Laporan Arus Kas \\
\hline 6. & Laporan Perubahan Ekuitas Pemilik \\
\hline 7. & Laporan Sumber dan Penyaluran Dana Zakat \\
\hline 8. & Laporan Sumber dan Penggunaan Dana Qardh \\
\hline
\end{tabular}

Tabel 3.1 Menampilkan Total Item yang diambil Sebagai standar AAOIFI

\section{Standar IFRS}

Dalam penelitian ini standar IFRS diukur menggunakan item-item yang diiperlukan diantaranya:

\begin{tabular}{|l|l|}
\hline No & Kategori Item Yang Diperlukan \\
\hline 1. & Informasi perusahaan \\
\hline
\end{tabular}




\begin{tabular}{|l|l|}
\hline 2. & Struktur Modal \\
\hline 3. & Kecukupan Modal \\
\hline 4. & Resiko Kredit \\
\hline 5. & Resiko Likuiditas \\
\hline 6. & Resiko Pasar \\
\hline 7. & Resiko Operasional \\
\hline 8. & Pengungkapan Tata Kelola Perbankan \\
\hline
\end{tabular}

\section{Deskripsi Objek Penelitian}

Dalam penelitian ini peneliti menggunakan laporan keuangan perbankan syariah dalam periode tahun 2014-2018. Bank syariah yang dijadikan sempel dalam penelitian ini adalah sebanyak 11 bank. Adapun data bank syariah yang akan dijadikan sampel dalam penelitian ini adalah sebagai berikut:

\begin{tabular}{|c|c|c|}
\hline NO & $\begin{array}{c}\text { PERBANKAN SYARIAH } \\
\text { INDONESIA }\end{array}$ & WEBSITE \\
\hline 1 & PT.Bank Syariah Mandiri (A) & www.banksyariahmandiri.co.id \\
\hline 2 & PT. BNI Syariah (B) & www.bnisyariah.co.id \\
\hline 3 & PT.BRI Syariah (C) & www.brisyariah.co.id \\
\hline 4 & PT.BCA syariah (D) & www.bcasyariah.co.id \\
\hline 5 & $\begin{array}{l}\text { PT. Bank Muamalat Indonesia } \\
\text { (E) }\end{array}$ & www.bankmuamalat.co.id \\
\hline 6 & PT. Bank Syariah Mega.tbk (F) & $\underline{\text { www.megasyariah.co.id }}$ \\
\hline 7 & PT. Bukopin Syariah (G) & www.syariahbukopin.co.id \\
\hline 8 & $\begin{array}{l}\text { PT. Maybank Syariah Indone- } \\
\text { sia }(\mathrm{H})\end{array}$ & www.maybanksyariah.co.id \\
\hline 9 & $\begin{array}{l}\text { PT. Bank Jabar Banten syariah } \\
\text { (I) }\end{array}$ & www.bjbsyariah.co.id \\
\hline 10 & PT. Bank Panin syariah (J) & www.paninbanksyariah.co.id \\
\hline 11 & PT.Bank Victoria syariah (K) & www.bankvictoriasyariah.co.id \\
\hline
\end{tabular}

Tabel 4.1 Daftar perbankan syariah yang ada di Indonesia

\section{Hasil analisis perbandingan isi laporan keuangan perbankan syariah di Indonesia}

Adapun perbandingan isi laporan keuangan yang dapat dijadikan pertimbangan dalam menganalisis pelaporan/pencatatan dalam laporan keuangan antar beberapa bank perbankan syariah di Indonesia adalah sebagai berikut:

Tabel 4.4 Jumlah item standar AAOIFI yang diadopsi di perbankan Syariah Indonesia 


\begin{tabular}{|c|c|c|c|c|c|c|c|c|c|c|c|c|c|c|c|c|c|}
\hline \multirow[t]{2}{*}{$\begin{array}{l}\text { Nama } \\
\text { Bank }\end{array}$} & \multirow[t]{2}{*}{ Tahun } & \multicolumn{2}{|c|}{$\begin{array}{c}\text { Ke- } \\
\text { tentuan } \\
\text { Umum } \\
\text { laporan } \\
\text { keu- } \\
\text { angan }\end{array}$} & \multicolumn{2}{|c|}{$\begin{array}{c}\text { Pengungk } \\
\text { apan } \\
\text { Umum } \\
\text { Dalam } \\
\text { Laporan } \\
\text { Keuangan }\end{array}$} & \multicolumn{2}{|c|}{$\begin{array}{c}\text { Laporan } \\
\text { Posisi } \\
\text { Keuangnn } \\
\text { (Neraca) }\end{array}$} & \multicolumn{2}{|c|}{$\begin{array}{c}\text { Laporan } \\
\text { Laba } \\
\text { Rugi }\end{array}$} & \multicolumn{2}{|c|}{$\begin{array}{c}\text { Laporan } \\
\text { Arus } \\
\text { Kas }\end{array}$} & \multicolumn{2}{|c|}{$\begin{array}{l}\text { Laporan } \\
\text { Peru- } \\
\text { bahan } \\
\text { Ekuitas } \\
\text { Pemilik }\end{array}$} & \multicolumn{2}{|c|}{$\begin{array}{c}\text { Laporan } \\
\text { Sumber } \\
\text { dan Pen- } \\
\text { yaluran } \\
\text { Dana Za- } \\
\text { kat }\end{array}$} & \multicolumn{2}{|c|}{$\begin{array}{c}\text { Lapora } \\
\text { n Sum- } \\
\text { ber dan } \\
\text { Penggu } \\
\text { naan } \\
\text { Dana } \\
\text { Qardh }\end{array}$} \\
\hline & & I & II & I & II & I & II & $\mathbf{I}$ & II & I & II & I & II & I & II & I & II \\
\hline \multirow{5}{*}{$\begin{array}{l}\text { PT.Bank } \\
\text { Syariah } \\
\text { Mandiri } \\
\text { (A) }\end{array}$} & 2014 & 5 & 5 & 5 & 5 & 5 & 5 & 5 & 5 & 5 & 5 & 5 & 5 & 5 & 5 & 5 & 5 \\
\hline & 2015 & 5 & 5 & 5 & 5 & 5 & 5 & 5 & 5 & 5 & 5 & 5 & 5 & 5 & 5 & 5 & 5 \\
\hline & 2016 & 5 & 5 & 5 & 5 & 5 & 5 & 5 & 5 & 5 & 5 & 5 & 5 & 5 & 5 & 5 & 5 \\
\hline & 2017 & 5 & 5 & 5 & 5 & 5 & 5 & 5 & 5 & 5 & 5 & 5 & 5 & 5 & 5 & 5 & 5 \\
\hline & 2018 & 5 & 5 & 5 & 5 & 5 & 5 & 5 & 5 & 5 & 5 & 5 & 5 & 5 & 5 & 5 & 5 \\
\hline \multirow{5}{*}{$\begin{array}{c}\text { PT. BNI } \\
\text { Syariah } \\
\text { (B) }\end{array}$} & 2014 & 5 & 3 & 5 & 5 & 5 & 5 & 5 & 5 & 5 & 5 & 5 & 5 & 5 & 5 & 5 & 5 \\
\hline & 2015 & 5 & 5 & 5 & 5 & 5 & 5 & 5 & 5 & 5 & 5 & 5 & 5 & 5 & 5 & 5 & 5 \\
\hline & 2016 & 5 & 5 & 5 & 5 & 5 & 5 & 5 & 5 & 5 & 5 & 5 & 5 & 5 & 5 & 5 & 5 \\
\hline & 2017 & 5 & 5 & 5 & 5 & 5 & 5 & 5 & 5 & 5 & 5 & 5 & 5 & 5 & 5 & 5 & 5 \\
\hline & 2018 & 5 & 5 & 5 & 5 & 5 & 5 & 5 & 5 & 5 & 5 & 5 & 5 & 5 & 5 & 5 & 5 \\
\hline \multirow{2}{*}{$\begin{array}{l}\text { PT.BRI } \\
\text { Syariah } \\
\text { (C) }\end{array}$} & 2014 & 5 & 5 & 5 & 5 & 5 & 5 & 5 & 5 & 5 & 5 & 5 & 5 & 5 & 5 & 5 & 5 \\
\hline & 2015 & 5 & 5 & 5 & 5 & 5 & 5 & 5 & 5 & 5 & 5 & 5 & 5 & 5 & 5 & 5 & 5 \\
\hline
\end{tabular}

\begin{tabular}{|c|c|c|c|c|c|c|c|c|c|c|c|c|c|c|c|c|c|}
\hline & 2016 & 5 & 5 & 5 & 5 & 5 & 5 & 5 & 5 & 5 & 5 & 5 & 5 & 5 & 5 & 5 & $s$ \\
\hline & 2017 & 5 & 5 & 5 & 5 & 5 & 5 & 5 & 5 & 5 & 5 & 5 & 5 & 5 & 5 & 5 & $s$ \\
\hline & 2018 & 5 & 5 & 5 & 5 & 5 & 5 & 5 & 5 & 5 & 5 & 5 & 5 & 5 & 5 & $s$ & 5 \\
\hline \multirow{5}{*}{$\begin{array}{c}\text { DT.ECA } \\
\text { Myariah } \\
\left(D^{\prime}\right)\end{array}$} & 2014 & 5 & 5 & 5 & 5 & 5 & 5 & 5 & 5 & 5 & 5 & 5 & 5 & 5 & 5 & 5 & 3 \\
\hline & 2015 & 5 & 5 & 5 & 5 & 5 & 5 & 5 & 5 & 5 & 5 & 5 & 5 & 5 & 5 & 5 & 4 \\
\hline & 2016 & 5 & 5 & 5 & 5 & 5 & 5 & 5 & 5 & 5 & 5 & 5 & 5 & 5 & 5 & 5 & 3 \\
\hline & 2017 & 5 & 5 & 5 & 5 & 5 & 5 & 5 & 5 & 5 & 5 & 5 & 5 & 5 & 5 & 5 & 3 \\
\hline & 2018 & 5 & 5 & 5 & 5 & 5 & 5 & 5 & 5 & 5 & 5 & 5 & 5 & 5 & 5 & 5 & 4 \\
\hline \multirow{5}{*}{$\begin{array}{c}\text { DT. } \\
\text { Eank } \\
\text { Marama- } \\
\text { lat Inda- } \\
\text { necia } \\
\text { (E) }\end{array}$} & 2014 & 5 & 5 & 5 & 5 & 5 & 5 & 5 & 5 & 5 & 5 & 5 & 5 & 5 & 5 & 5 & 4 \\
\hline & 2015 & 5 & 5 & 5 & 5 & 5 & 5 & 5 & 5 & 5 & 5 & 5 & 5 & 5 & 5 & 5 & 5 \\
\hline & 2016 & 5 & 5 & 5 & 5 & 5 & 5 & 5 & 5 & 5 & 5 & 5 & 5 & 5 & 5 & 5 & 5 \\
\hline & 2017 & 5 & 5 & 5 & 5 & 5 & 5 & 5 & 5 & 5 & 5 & 5 & 5 & 5 & 5 & 5 & 4 \\
\hline & 2018 & 5 & 5 & 5 & 5 & 5 & 5 & 5 & 5 & 5 & 5 & 5 & 5 & 5 & 5 & 5 & 5 \\
\hline \multirow{5}{*}{$\begin{array}{c}\text { PT. } \\
\text { Bank } \\
\text { Svaribh } \\
\text { Mrgast } \\
\text { beos }\end{array}$} & 2014 & 5 & 2 & 5 & 5 & 5 & 5 & 5 & 5 & 5 & 5 & 5 & 5 & 5 & 5 & 5 & 3 \\
\hline & 2015 & 5 & 5 & 5 & 5 & 5 & 5 & 5 & 5 & 5 & 5 & 5 & 5 & 5 & 5 & 5 & 5 \\
\hline & 2016 & 5 & 5 & 5 & 5 & 5 & 5 & 5 & 5 & 5 & 5 & 5 & 5 & 5 & 5 & 5 & $s$ \\
\hline & 2017 & 5 & 5 & 5 & 5 & 5 & 5 & 5 & 5 & 5 & 5 & 5 & 5 & 5 & 5 & 5 & 4 \\
\hline & 2018 & 5 & 5 & 5 & 5 & 5 & 5 & 5 & 5 & 5 & 5 & 5 & 5 & 5 & 5 & 5 & 5 \\
\hline \multirow{5}{*}{$\begin{array}{c}\text { DT. EE- } \\
\text { kopin } \\
\text { Svaria } \\
\text { helGi }\end{array}$} & 2014 & 5 & 5 & 5 & 5 & 5 & 5 & 5 & 5 & 5 & 5 & 5 & 5 & 5 & 5 & 5 & 4 \\
\hline & 2015 & 5 & 5 & 5 & 5 & 5 & 5 & 5 & 5 & 5 & 5 & 5 & 5 & 5 & 5 & 5 & 5 \\
\hline & 2016 & 5 & 5 & 5 & 5 & 5 & 5 & 5 & 5 & 5 & 5 & 5 & 5 & 5 & 5 & 5 & 5 \\
\hline & 2017 & 5 & 5 & 5 & 5 & 5 & 5 & 5 & 5 & 5 & 5 & 5 & 5 & 5 & 5 & 5 & 4 \\
\hline & 2018 & 5 & 5 & 5 & 5 & 5 & 5 & 5 & 5 & 5 & 5 & 5 & 5 & 5 & 5 & 5 & 5 \\
\hline \multirow{5}{*}{$\begin{array}{c}\text { PT. } \\
\text { MUyy } \\
\text { bonk } \\
\text { Syarim } \\
\text { h } \\
\text { Indone } \\
\text { - mim } \\
\text { (H) }\end{array}$} & 2014 & 5 & 4 & 5 & 5 & 5 & 5 & 5 & 5 & 5 & 5 & 5 & 5 & 5 & 5 & 5 & 3 \\
\hline & 2015 & 5 & 5 & 5 & 5 & 5 & 5 & 5 & 5 & 5 & 5 & 5 & 5 & 5 & 5 & 5 & 5 \\
\hline & 2016 & 5 & 5 & 5 & 5 & 5 & 5 & 5 & 5 & 5 & 5 & 5 & 5 & 5 & 5 & 5 & 5 \\
\hline & 2017 & 5 & 5 & 5 & 5 & 5 & 5 & 5 & 5 & 5 & 5 & 5 & 5 & 5 & 5 & 5 & 4 \\
\hline & 2018 & 5 & 5 & 5 & 5 & 5 & 5 & 5 & 5 & 5 & 5 & 5 & 5 & 5 & 5 & 5 & 5 \\
\hline \multirow{5}{*}{ 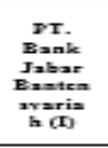 } & 2014 & 5 & 5 & 5 & 5 & 5 & 5 & 5 & 5 & 5 & 5 & 5 & 5 & 5 & 3 & 5 & 5 \\
\hline & 2015 & 5 & 5 & 5 & 5 & 5 & 5 & 5 & 5 & 5 & 5 & 5 & 5 & 5 & 5 & 5 & $s$ \\
\hline & 2016 & 5 & 5 & 5 & 5 & 5 & 5 & 5 & 5 & 5 & 5 & 5 & 5 & 5 & 5 & 5 & 5 \\
\hline & 2017 & 5 & 5 & 5 & 5 & 5 & 5 & 5 & 5 & 5 & 5 & 5 & 5 & 5 & 5 & 5 & 5 \\
\hline & 2018 & 5 & 5 & 5 & 5 & 5 & 5 & 5 & 5 & 5 & 5 & 5 & 5 & 5 & 5 & 5 & 5 \\
\hline \multirow{5}{*}{$\begin{array}{c}\text { DT. } \\
\text { Bank } \\
\text { Dania } \\
\text { yyaria } \\
\text { h }\{(D)\end{array}$} & 2014 & 5 & 4 & 5 & 5 & 5 & 5 & 5 & 5 & 5 & 5 & 5 & 5 & 5 & 3 & 5 & 4 \\
\hline & 2015 & 5 & 5 & 5 & 5 & 5 & 5 & 5 & 5 & 5 & 5 & 5 & 5 & 5 & 5 & 5 & 5 \\
\hline & 2016 & 5 & 5 & 5 & 5 & 5 & 5 & 5 & 5 & 5 & 5 & 5 & 5 & 5 & 5 & 5 & 5 \\
\hline & 2017 & 5 & 5 & 5 & 5 & 5 & 5 & 5 & 5 & 5 & 5 & 5 & 5 & 5 & 5 & 5 & 5 \\
\hline & 2018 & 5 & 5 & 5 & 5 & 5 & 5 & 5 & 5 & 5 & 5 & 5 & 5 & 5 & 5 & 5 & 5 \\
\hline \multirow{3}{*}{ 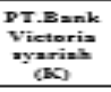 } & 2014 & 5 & 4 & 5 & 5 & 5 & 5 & 5 & 5 & 5 & 5 & 5 & 5 & 5 & 3 & 5 & 3 \\
\hline & 2015 & 5 & 5 & 5 & 5 & 5 & 5 & 5 & 5 & 5 & 5 & 5 & 5 & 5 & 3 & 5 & 4 \\
\hline & 2016 & 5 & 5 & 5 & 5 & 5 & 5 & 5 & 5 & 5 & 5 & 5 & 5 & 5 & 5 & 5 & $s$ \\
\hline & 2017 & 5 & 5 & 5 & 5 & 5 & 5 & 5 & 5 & 5 & 5 & 5 & 5 & 5 & 5 & 5 & 5 \\
\hline & 2018 & 5 & 5 & 5 & 5 & 5 & 5 & 5 & 5 & 5 & 5 & 5 & 5 & 5 & 5 & 5 & 5 \\
\hline
\end{tabular}

Sumber: Laporan tahunan perbankan Syariah. Keterangan: I=Item yang diinginkan, II = Item yang diungkapkan

Tabel 4.5 Total Item standar IFRS yang diadopsi di Perbankan Syariah Indonesia 


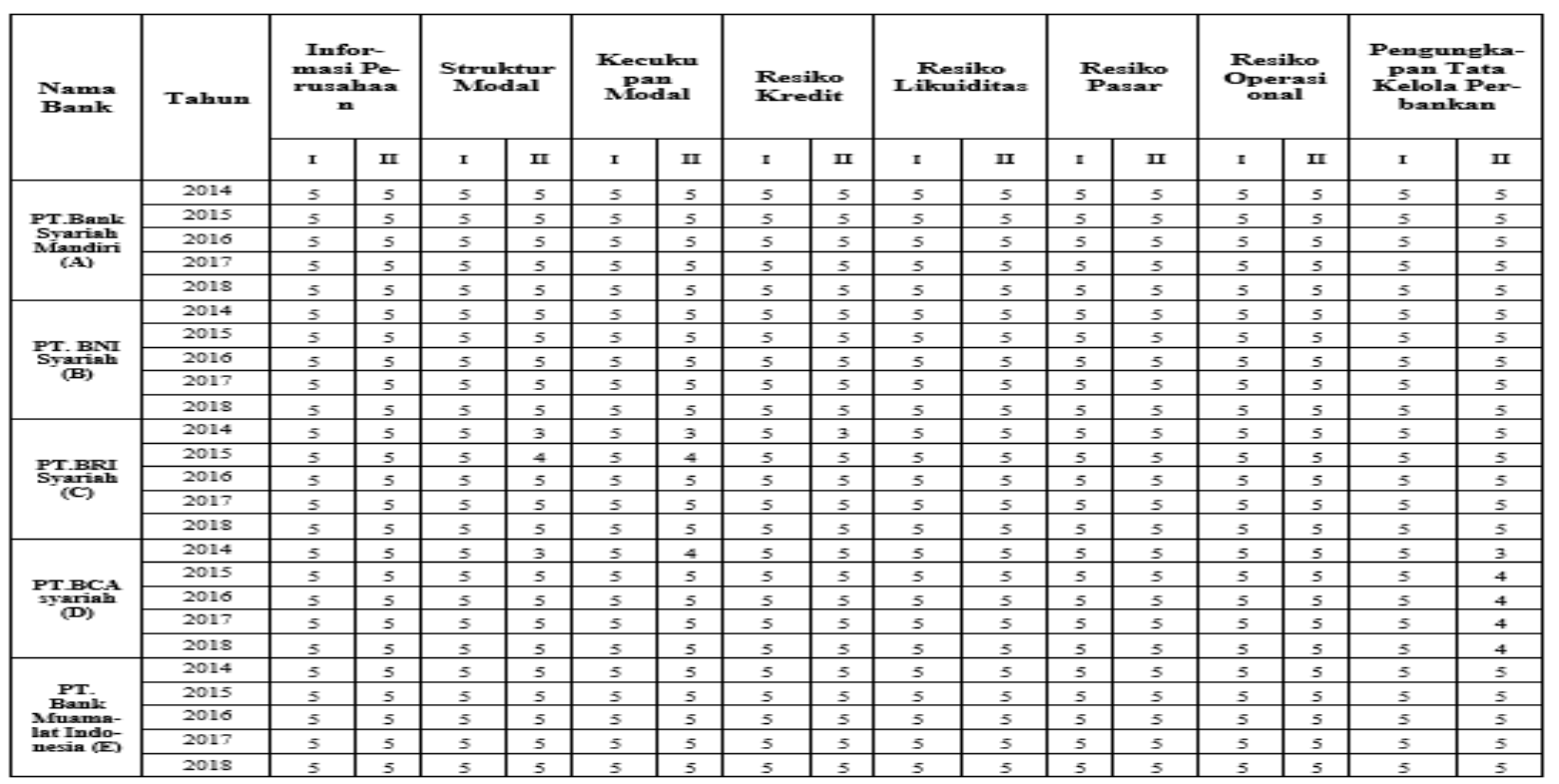

\begin{tabular}{|c|c|c|c|c|c|c|c|c|c|c|c|c|c|c|c|c|c|}
\hline & 2014 & 5 & 5 & 5 & 3 & 5 & 4 & 5 & 4 & 5 & 4 & 5 & 4 & 5 & 4 & 5 & 5 \\
\hline \multirow{5}{*}{ 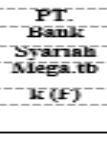 } & 2015 & 5 & 5 & 5 & 5 & 5 & 5 & 5 & 5 & 5 & 5 & 5 & 5 & 5 & 5 & 5 & 5 \\
\hline & 2016 & 5 & 5 & 5 & 5 & 5 & 5 & 5 & 5 & 5 & 5 & 5 & 5 & 5 & 5 & 5 & 5 \\
\hline & 2017 & 5 & 5 & 5 & 5 & 5 & 5 & 5 & . & 5 & 5 & 5 & 5 & 5 & 5 & 5 & 5 \\
\hline & 2018 & 5 & 5 & 5 & 5 & 5 & 5 & 5 & 5 & 5 & 5 & 5 & 5 & 5 & 5 & 5 & 5 \\
\hline & 2014 & 5 & 5 & 5 & 5 & 5 & 5 & 5 & 5 & 5 & 5 & 5 & 5 & 5 & 5 & 5 & 5 \\
\hline \multirow{4}{*}{$\begin{array}{l}\text { PT. Bu- } \\
\text { LEpin } \\
\text { Syaniah } \\
\text { (G) }\end{array}$} & 2015 & 5 & 5 & 5 & 5 & 5 & 5 & 5 & 5 & 5 & 5 & 5 & 5 & 5 & 5 & 5 & 5 \\
\hline & 2016 & 5 & 5 & 5 & 5 & 5 & 5 & 5 & 5 & 5 & 5 & 5 & 5 & 5 & 5 & 5 & 5 \\
\hline & 2017 & 5 & 5 & 5 & 5 & 5 & 5 & 5 & 5 & 5 & 5 & 5 & 5 & 5 & 5 & 5 & 5 \\
\hline & 2018 & 5 & 5 & 5 & 5 & 5 & 5 & 5 & 5 & 5 & 5 & 5 & 5 & 5 & 5 & 5 & 5 \\
\hline \multirow{5}{*}{ 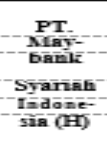 } & 2014 & 5 & 5 & 5 & 5 & 5 & 5 & 5 & 5 & 5 & 5 & 5 & 5 & 5 & 5 & 5 & 5 \\
\hline & 2015 & 5 & 5 & 5 & 5 & 5 & 5 & 5 & 5 & 5 & 5 & 5 & 5 & 5 & 5 & 5 & 5 \\
\hline & 2016 & 5 & 5 & 5 & 5 & 5 & 5 & 5 & 5 & 5 & 5 & 5 & 5 & 5 & 5 & 5 & 5 \\
\hline & 2017 & 5 & 5 & 5 & 5 & 5 & 5 & 5 & 5 & 5 & 5 & 5 & 5 & 5 & 5 & 5 & 5 \\
\hline & 2018 & 5 & 5 & 5 & 5 & 5 & 5 & 5 & 5 & 5 & 5 & 5 & 5 & 5 & 5 & 5 & 5 \\
\hline \multirow{5}{*}{ 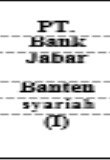 } & 2014 & 5 & 5 & 5 & 5 & 5 & 5 & 5 & 5 & 5 & 5 & 5 & 5 & 5 & 3 & 5 & 3 \\
\hline & 2015 & 5 & 5 & 5 & 5 & 5 & 5 & 5 & 5 & 5 & 5 & 5 & 5 & 5 & 5 & 5 & 5 \\
\hline & 2016 & 5 & 5 & 5 & 5 & 5 & 5 & 5 & 5 & 5 & 5 & 5 & 5 & 5 & 5 & 5 & 5 \\
\hline & 2017 & 5 & 5 & 5 & 5 & 5 & 5 & 5 & 5 & 5 & 5 & 5 & 5 & 5 & 5 & 5 & 5 \\
\hline & 2018 & 5 & 5 & 5 & 5 & 5 & 5 & 5 & 5 & 5 & 5 & 5 & 5 & 5 & 5 & 5 & 5 \\
\hline \multirow{6}{*}{ 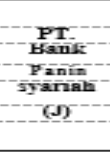 } & 2014 & 5 & 5 & 5 & 5 & 5 & 5 & 5 & 5 & 5 & 5 & 5 & 5 & 5 & 3 & 5 & 2 \\
\hline & 2015 & 5 & 5 & 5 & 5 & 5 & 5 & 5 & 5 & 5 & 5 & 5 & 5 & 5 & 5 & 5 & 5 \\
\hline & 2016 & 5 & 5 & 5 & 5 & 5 & 5 & 5 & 5 & 5 & 5 & 5 & 5 & 5 & 5 & 5 & 5 \\
\hline & 2013 & 5 & 5 & 5 & 5 & 5 & 5 & 5 & 5 & 5 & 5 & 5 & 5 & 5 & 5 & 5 & 5 \\
\hline & 2018 & 5 & 5 & 5 & 5 & 5 & 5 & 5 & 4 & 5 & 4 & 5 & 4 & 5 & 4 & 5 & 4 \\
\hline & 2014 & 5 & 5 & 5 & 5 & 5 & 5 & 5 & 5 & 5 & 5 & 5 & 5 & 5 & 2 & 5 & 2 \\
\hline \multirow{4}{*}{$\begin{array}{l}\text { PT.Bank } \\
\text { VIctorna } \\
\text { syaniak } \\
\text { (K) }\end{array}$} & 2015 & 5 & 5 & 5 & 5 & 5 & 5 & 5 & 5 & 5 & 5 & 5 & 5 & 5 & 3 & 5 & 3 \\
\hline & 2016 & 5 & 5 & 5 & 5 & 5 & 5 & 5 & 5 & 5 & 5 & 5 & 5 & 5 & 5 & 5 & 5 \\
\hline & 2017 & 5 & 5 & 5 & 5 & 5 & 5 & 5 & 5 & 5 & 5 & 5 & 5 & 5 & 5 & 5 & 5 \\
\hline & 2018 & 5 & 5 & 5 & 5 & 5 & 5 & 5 & 5 & 5 & 5 & 5 & 5 & 5 & 5 & 5 & 5 \\
\hline
\end{tabular}

\section{HASIL DAN PEMBAHASAN}

Berdasarkan total item yang diambil sebagai standar AAOIFI dan IFRS peneliti memasukkan content atau daftar isi laporan keuangan dalam penelitian ini bertujuan untuk membandingkan tingkat kecenderungan bank syariah Indonesia sejauh mana dalam mengadopsi standar AAOIFI dan standar IFRS.Dari hasil analisis diatas, dapat disimpulkan masing-masing item bahwa:

1. Ketentuan umum laporan keuangan Bank Syariah Mandiri (A) memiliki 5 item yang diungkapkan dari 5 item yang diinginkan,sehingga ketentuan umum laporan keuangan 
Bank Syariah memiliki persentase sebanyak (100\%) begitu pula dengan pengungkapan umum dalam laporan keuangan, laporan posisi keuangan (neraca), laporan laba rugi, laporan arus kas, laporan perubahan ekuitas,laporan sumber dan penyaluran dana zakat, laporan dan penggunaan dana Qardh masing-masing memiliki 5 item yang diungkapkan dari 5 item yang diinginkan, dimana masing-masing total item memiliki persentase sebesar (100\%) ,hal ini berarti bahwa Bank Syariah Mandiri memenuhi standar total item yang diambil sebagai standar AAOIFI sebesar (100\%), sedangkan untuk informasi perusahaan, struktur modal, kecukupan modal,resiko kredit, resiko likuiditas,resiko operasional, resiko pasar ,pengungkapan tata kelola perbankan, masing-masing memiliki persenatase sebesar (100\%), hal ini berarti bahwa Bank Syariah Mandiri juga memenuhi standar total item yang diambil sebagai standar IFRS sebesar $(100 \%)$

2. Ketentuan umum laporan keuangan BNI Syariah (B) memiliki 3 item yang diungkapkan dari 5 item yang diinginkan yang memiliki nilai sebesar (92\%), sementara pengungkapan umum dalam laporan keuangan, laporan posisi keuangan (neraca), laporan laba rugi, laporan arus kas, laporan perubahan ekuitas,laporan sumber dan penyaluran dana zakat, laporan dan penggunaan dana Qardh masingmasing memiliki 5 item yang diungkapkan dari 5 item yang diinginkan dimana masing-masing memiliki persentase sebesar (100\%), hal ini berarti bahwa BNI Syariah memenuhi standar total item yang diambil sebagai standar AAOIFI sebesar (99\%), sedangkan untuk informasi perusahaan, struktur modal, kecukupan modal,resiko kredit, resiko likuiditas,resiko operasional, resiko pasar ,pengungkapan tata kelola perbankan, masing-masing memiliki persentase sebesar $(100 \%)$, hal ini berarti bahwa Bank Syariah Mandiri memenuhi standar total item yang diambil sebagai standar IFRS sebesar (100\%)

3. BRI Syariah (C) memiliki ketentuan umum laporan keuangan,pengungkapan umum dalam laporan keuangan, laporan posisi keuangan (neraca), laporan laba rugi, laporan arus kas, laporan perubahan ekuitas,laporan sumber dan penyaluran dana zakat, laporan dan penggunaan dana Qardh masing-masing memiliki 5 item yang diungkapkan dari 5 item yang diinginkan dimana masing- masing memiliki persentase sebesar $(100 \%)$, hal ini berarti bahwa BRI Syariah memenuhi standar total item yang diambil sebagai standar AAOIFI sebesar (100\%), sedangkan untuk total item standar IFRS BRI Syariah memiliki nilai untuk masing - masing item sebagi berikut, 
informasi perusahaan (100\%), struktur modal (88\%), kecukupan modal (88\%),resiko kredit (92\%), resiko likuiditas (100\%), resiko operasional (100\%), resiko pasar (100\%) ,pengungkapan tata kelola perbankan (100\%), sehingga total dari keseluruhan total item yang diambil sebagai standar IFRS oleh BRI Syariah adalah sebesar (96\%)

4. Sementara itu BCA syariah (D) memiliki Ketentuan umum laporan keuangan , pengungkapan umum dalam laporan keuangan, laporan posisi keuangan (neraca), laporan laba rugi, laporan arus kas, laporan perubahan ekuitas dan laporan sumber dan penyaluran dana zakat masing- masing memiliki persentase sebesar (100\%), sementara laporan dan penggunaan dana Qardh memiliki persentase sebesar (68\%) hal ini berarti bahwa BCA Syariah memenuhi standar total item yang diambil sebagai standar AAOIFI sebesar (96\%), sedangkan untuk informasi perusahaan (100\%), struktur modal (92\%), kecukupan modal (96\%),sementara resiko kredit, resiko likuiditas,resiko operasional, resiko pasar,pengungkapan tata kelola perbankan, masing-masing memiliki persentase sebesar (100\%) sehingga total keseluruhan dari total item yang diambil sebagai standar IFRS adalah sebesar (96\%)

5. Bank Muamalat Indonesia (E) memiliki persentase ketentuan umum laporan keuangan, pengungkapan umum dalam laporan keuangan, laporan posisi keuangan (neraca), laporan laba rugi, laporan arus kas, laporan perubahan ekuitas dan laporan sumber dan penyaluran dana zakat masing-masing memiliki persentase sebesar $(100 \%)$, sementara laporan dan penggunaan dana Qardh memiliki persentase sebesar (92\%), hal ini berarti bahwa Bank Muamalat Indonesia memenuhi standar total item yang diambil sebagai standar AAOIFI sebesar (99\%),sedangkan untuk total item untuk standar IFRS Bank Muamalat Indonesia masing-masing memiliki persentase sebesar (100\%) hal ini berarti Bank Muamalat Indonesia memenuhi standar total item yang diambil sebagai standar IFRS sebesar (100\%).

6. Bank Syariah Mega.tbk (F) memiliki persentase sebagai berikut, ketentuan umum laporan keuangan (88\%), pengungkapan umum dalam laporan keuangan (100\%), laporan posisi keuangan (neraca) (100\%), laporan laba rugi (100\%), laporan arus kas $(100 \%)$, laporan perubahan ekuitas (100\%), laporan sumber dan penyaluran dana zakat (100\%), laporan dan penggunaan dana Qardh (84\%) sehingga total keseluruhan dari total item untuk standar AAOIFI memiliki persentase sebesar (97\%), sementara itu untuk informasi perusahaan (100\%), struktur modal (92\%), kecukupan modal ,resiko kredit, resiko likuiditas,resiko operasional, resiko pasar, masing-masing memiliki 
persentase sebesar (96\%) dan pengungkapan tata kelola perbankan (100\%), sehingga total keseluruhan dari total item yang diambil sebagai standar IFRS Bank Syariah Mega.tbk adalah sebesar (97\%)

7. Bukopin Syariah (G) memiliki persentase ketentuan umum laporan keuangan,pengungkapan umum dalam laporan keuangan, laporan posisi keuangan (neraca), laporan laba rugi, laporan arus kas, laporan perubahan ekuitas dan laporan sumber dan penyaluran dana zakat masing-masing memiliki persentase sebesar (100\%), sementara laporan dan penggunaan dana Qardh memiliki persentase sebesar (92\%), ini berarti bahwa Bukopin Syariah memiliki jumlah keseluruhan dari total item yang diambil sebagai standar AAOIFI adalah sebesar (99\%), sementara itu untuk total item yang diambil sebagai standar IFRS, Bukopin Syariah memiliki persentase sebesar $(100 \%)$ dari masing-masing total item,sehingga total keseluruhan dari masing-masing total item di Bukopin Syariah yang diambil sebagai standar IFRS adalah sebesar $(100 \%)$

8. Maybank Syariah Indonesia $(\mathrm{H})$ memiliki persentase ketentuan umum laporan keuangan (96\%), pengungkapan umum dalam laporan keuangan, laporan posisi keuangan (neraca), laporan laba rugi, laporan arus kas, laporan perubahan ekuitas dan laporan sumber dan penyaluran dana zakat masing-masing memiliki persentase sebesar (100\%) ,sementara laporan dan penggunaan dana Qardh memiliki persentase sebesar (88\%), ini berarti bahwa Maybank Syariah Indonesia memiliki jumlah keseluruhan dari total item yang diambil sebagai standar AAOIFI adalah sebesar $(98 \%)$, sementara itu untuk total item yang diambil sebagai standar IFRS, Maybank Syariah memiliki persentase sebesar (100\%) dari masing-masing total item,sehingga total keseluruhan dari masing-masing total item di Maybank Syariah yang diambil sebagai standar IFRS adalah sebesar (100\%)

9. Bank Jabar Banten syariah (I) memiliki persentase ketentuan umum laporan keuangan sebesar (96\%), pengungkapan umum dalam laporan keuangan, laporan posisi keuangan (neraca), laporan laba rugi, laporan arus kas dan laporan perubahan ekuitas, masing-masing memiliki persentase sebesar (100\%), sementara laporan sumber dan penyaluran dana zakat (84\%), laporan dan penggunaan dana Qardh memiliki persentase sebesar (88\%), hal ini berarti bahwa Bank Jabar Banten Syariah memiliki jumlah keseluruhan item yang diambil sebagai standar AAOIFI sebesar (96\%), sedangkan untuk informasi perusahaan,struktur modal, kecukupan modal,resiko kredit, 
resiko likuiditas, , resiko pasar, masing-masing memiliki persentase sebesar (100\%) sementara itu resiko perasional dan pengungkapan tata kelola perbankan sama-sama memiliki persentase masing-masing (92\%) sehingga total keseluruhan dari total item yang diambil sebagai standar IFRS adalah sebesar (98\%).

10. Bank Panin syariah (J) memiliki persentase ketentuan umum laporan keuangan sebesar (96\%), pengungkapan umum dalam laporan keuangan, laporan posisi keuangan (neraca), laporan laba rugi, laporan arus kas dan laporan perubahan ekuitas,masing-masing memiliki persentase sebesar (100\%),sedangkan laporan sumber dan penyaluran dana zakat (92\%) sementara itu laporan dan penggunaan dana Qardh memiliki persentase sebesar (96\%), hal in berarti bahwa Bank Panin Syariah memiliki jumlah keseluruhan item yang diambil sebagai standar AAOIFI sebesar (98\%), sedangkan untuk informasi perusahaan,struktur modal dan kecukupan modal , masing-masing memiliki persentase sebesar (100\%), resiko kredit, resiko likuiditas, resiko pasar masing-masing memiliki persentase sebesar (96\%), sementara itu resiko operasional $(88 \%)$ serta pengungkapan tata kelola perbankan sama-sama memiliki persentase $(96 \%)$ sehingga total keseluruhan dari total item yang diambil sebagai standar IFRS adalah sebesar $(97 \%)$.

11. Sementara itu Bank Victoria syariah (K) memiliki ketentuan umum laporan keuangan sebesar (96\%), pengungkapan umum dalam laporan keuangan, laporan posisi keuangan (neraca), laporan laba rugi, laporan arus kas dan laporan perubahan ekuitas, masing-masing memiliki persentase sebesar (100\%) serta laporan sumber dan penyaluran dana zakat (84\%) dan laporan dan pengguanaan dana Qardh (88\%), hal ini berarti Bank Victoria Syariah memiliki jumlah keseluruhan item yang diambil sebagai standar AAOIFI adalah sebesar (96\%) sedangkan untuk informasi perusahaan,struktur modal, kecukupan modal,resiko kredit, resiko likuiditas, , resiko pasar, masing-masing memiliki persentase sebesar (100\%) sementara itu resiko operasional dan pengungkapan tata kelola perbankan,sama-sama memiliki persentase masing-masing (92\%) sehingga total keseluruhan dari total item yang diambil sebagai standar IFRS adalah sebesar (98\%).

Berdasarkan penjelasan diatas dapat disimpulkan bahwa perbankan syariah di Indonesia lebih condong mengadopsi standar IFRS dalam laporan keuangannya. Hal ini dibuktikan dengan besarnya persentase perbankan syariah yang dominan memenuhi total item yang dipilih sebagai standar IFRS. 


\section{PENUTUP}

\section{Kesimpulan}

Penelitian ini bertujuan untuk mengukur seberapa jauh perbankan syariah Indonesia mengadopsi standar IFRS dan AAOIFI. Analisis dilakukan pada laporan keuangan tahunan bank syariah periode tahun 2014-2018 yang terbagi dalam 11 perbankan syariah di Indonesia. Dengan menggunakan metode content analysis, dapat disimpulkan bahwa perbankan syariah Indonesia lebih condong mengadopsi standar IFRS dalam laporan keuangan tahunannya (annual report), hal ini dapat dibuktikan dengan besarnya jumlah persentase perbankan syariah yang dominan memenuhi total item yang dipilih sebagai standar IFRS dalam laporan keuangannya, dibandingkan dengan jumlah persentase perbankan syariah yang memenuhi total item yang dipilih sebagai standar AAOIFI.

\section{Saran}

Peneliti berharap penelitian ini dimasa yang akan datang diharapkan dapat memberikan manfaat dalam dunia pereekonomian islam, khususnya akuntansi syariah. Adapun saran yang dapat peneliti berikan adalah penelitian selanjutnya diharapkan untuk tidak membatasi penelitian hanya pada perbankan syariah saja, namun bisa mengambil lembaga keuangan syariah lain seperti, koperasi syariah, asuransi syariah dan lain-lain.

\section{DAFTAR PUSTAKA}

AAOIFI. 2002. "Governance Standards for Islamic Financial Institutions (AAOIFI) (2002)." Governance Standard for Islamic Financial Institutions, Manama, Bahrain.

Ajili, Hana, and Abdelfettah Bouri. 2017. "Comparative Study between IFRS and AAOIFI Disclosure Compliance: Evidence from Islamic Banks in Gulf Co- Operation Council Countries." Journal of Financial Reporting and Accounting 15(3): 269-92.

Azis, Indrawan. 2012. "Dampak Konvergensi International Financial Reporting Standartd ( IFRS ) Terhadap Pergeseran Prinsip Syariah ( Studi Kasus : PT Bank Muamalat Indonesia Tbk )." : 67-85.

Cahyonowati, Nur, and Dwi Ratmono. 2013. “Adopsi IFRS Dan Relevansi Nilai Informasi Akuntansi." Jurnal Akuntansi dan Keuangan 14(2): 105-15.

Eriyanto. 2004. Analisis Isi: Pengantar Metodologi Untuk Penelitian Komunikasi Dan Ilmu Sosial Lainnya.

Gamayuni, Rindu Rika. 2009. "Perkembangan Standar Akuntansi Keuangan Indonesia Menuju International Financial Reporting Standards." Jurnal Akuntansi dan Keuangan. 14.(2). 
Ganesha, Aldo, and Endang Kiswara. 2015. 4 Diponegoro Journal of Accounting FaktorFaktor Yang Mempengaruhi Tingkat Kepatuhan Perusahaan Go Public Pada Konvergensi International Financial Reporting Standard (Studi Empiris Pada Perusahaan Yang Terdaftar Di Index LQ45). http://ejournal3.undip.ac.id/index.php/ac counting/article/view/16508/15905.

Haniffa, Roszaini, and Mohammad Hudaib. 2007. "Exploring the Ethical Identity of Islamic Banks via Communication in Annual Reports." Journal of Business Ethics 76(1): 97-116.

Hermawan, Sigit, and Ety Nur Zunaida. 2013. "Analisis Kesiapan Dan Pelaksanaan Perkuliahan Akuntansi Berbasis Konvergensi International Financial Reporting Standarts (IFRS)." Jurnal Pendidikan Akuntansi 1(4).

Ibrahim, S H M. 2009. "IFRS vs. AAOIFI: The Clash of Standards? Munich Personal RePEc Archive (MPRA)."

Ikhsan, Arfan, and Herkulanus Bambang Suprasto. 2008. Teori Akuntansi \& Riset Multiparadigma. https://simdos.unud.ac.id/uploads/file_p endidikan_1_dir/14e0659a437a97db0a7 560d6644b766b.pdf.

Ilahiyah, Elthaf, and Elthaf MAR'A. 2012. "Pro Kontra Sistem Akuntansi Syariah Di Indonesia Terkait Konvergensi IFRS Di Indonesia.” Jurnal Akuntansi UNESA 1(1).

Indriantoro, Nur, and Bambang Supomo. 2014. "Metodologi Pneleitian Bisnis Untuk Akuntansi Dan Manajemen Edisi Pertama Cetakan Keenam.” BPFE. Yogyakarta.

Karim, R. A. A. 1999. Accounting in Islamic Financial Institutions. Accounting and Business Magazines.

Latifah, Ines Nur, Chusnul Asfadillah, and Raditya Sukmana. 2012. "History and Development of IFRS and AAOIFI and Their Future Challenge." In Cambridge Business \& Economics Conference, Cambridge, MA, , 27-28.

Lestari, Yona Octiani. 2013. "Konvergensi International Financial Reporting Standards (IFRS) Dan Manajemen Laba Di Indonesia.” El Muhasaba: Jurnal Akuntansi 2.(2).

Listiana, L. 2016. “Analisis Tingkat Kepatuhan Perbankan Syariah Terhadap On, Pengungkapan Menurut Ketentuan Syariah $=$ Syariah Compliance Analysis Guidelines., Disclosure of Islamic Banking According to Syariah Compliance Indonesia." Tesis Universitas Indonesia.

Meilita, Hani, and Purnama Subardi. 2019. "Kebutuhan AAOIFI Sebagai Standar Akuntansi Keuangan Syariah Dalam Harmonisasi Penyajian Laporan Keuangan.” 3(1): 16-20.

Nundini, Audita Ananda, and Hexana Sri Lastanti. 2014. "Pengaruh Konvergensi Ifrs Dan Mekanisme Corporate Governance Terhadap Earning Management Pada Perusahaan Manufaktur Yang Terdaftar Di Bursa Efek Indonesia.” Jurnal Akuntansi Trisakti 1(2): 19-32.

Nurhayati, Ida, and Maryono. 2012. “Keuangan Terhadap International Financial Reporting Standards ( Ifrs ) Pada Perusahaan Yang Terdaftar Di Bursa Efek ( Studi Kasus Perusahaan Manufaktur )." : 1-18.

Nurhayati, Sri Wasilah. 2009. Akuntansi Syariah Di Indonesia. Jakarta : Salemba Empat.

Pomeranz, Felix. 1997. "The Accounting and Auditing Organization for Islamic Financial Institutions: An Important Regulatory Debut." Journal of International Accounting, 
Auditing and Taxation 6(1): 123-30.

Purnamasari, Gusti Ayu Yuliani. 2016. "Analisis Perbandingan Kinerja Keuangan Bank Konvensional Dan Bank Syariah Periode 2010-2014." E-Jurnal Akuntansi Universitas Udayana Fakultas Ekonomi dan Bisnis Universitas Udayana ( Unud ) 15(1): 82-110.

Supomo, Bambang, and Nur Indriantoro. 2002. "Metodologi Penelitian Bisnis Untuk Akuntansi Dan Manajemen.” Yogyakarta: BPFE.

Ullah, Hafij, and Tabassum Tasnim. 2017. "Comparative Compliance Status of AAOIFI and IFSB Standards : An Empirical Evidence from Islami Bank Bangladesh Limited." Journal of Islamic Accounting and Business Research 9(4): 607-28.

Widiana. 2017. “Analisa Perkembangan Peraturan Dan Penerapan Akuntansi Syariah Di Indonesia." Jurnal Law and Justice 2(2): 168-76.

Yaya, Rizal, Aji Erlangga Martawireja, and Ahim Abdurahim. 2014. Akuntansi Perbankan Syariah: Teori Dan Praktik Kontemporer Berdasarkan PAPSI 2013 Edisi 2. Salemba Empat. 